\title{
Critical Review of M-Learning in Total Quality Management Classroom Practice in an Indonesian Private University
}

\author{
https://doi.org/10.3991/ijim.v14i20.15141 \\ Bunyamin ${ }^{\varpi}$, Khoerul Umam, Lismawati \\ Universitas Muhammadiyah Prof. Dr. Hamka, Jakarta, Indonesia \\ bunyamineuhamka.ac.id
}

\begin{abstract}
The widespread use of mobile phones has changed learning practices in the classroom. Many studies have already recommended the advantages of using mobile phones to teach religious education to university students. However, there is a lack of evidence for these advantages in the context of religious education. This research aims to test the effectiveness of Mlearning's utilization in educational programmes for Islamic religion teachers in a private university in Jakarta. A total of 41 pre-service teachers participated in this research. Various methods of data collection are used, including observation, written journals, students' responses, and tests. Subsequently, the data are analysed utilizing both quantitative and qualitative methods. The findings show that M-learning encourages students' awareness of conducting independent learning, creates a very interactive discussion atmosphere in class, and improves students' communication skills in the learning process. However, numerous technical challenges are found in the implementation of M-learning, such as regarding skill in using applications, internet access, and essay tests. The findings of this research offer recommendations to fellow educators regarding using this as an alternative solution.
\end{abstract}

Keywords-M-Learning, TQM Classroom, Communications

\section{Introduction}

The rapid growth of smartphone use is making mobile learning (M-learning) more popular in teaching and learning at university level [1]. Particularly in the Interactive Cellular Technology Journal (ICTJ), we have identified at least six studies that investigate the application of M-learning in learning practice at university, such as[2][7]. One study recommends that the practice of M-learning offers students an opportunity to control the learning process independently, without constraints of time and space. This independent learning opportunity supports the construction of material comprehension before teaching-learning activities in classroom. How students control independent learning, according to Tapia-Moreno and Villa-Martinez [5] and Cavus and Ibrahim [8], can help students to develop extensive material comprehension that is not limited to mobile learning provided by teachers. This 
comprehension development process is encouraged by enormous curiosity, which allows access to abundant relevant knowledge that strengthens students' comprehension of the materials[9], [10]. On the other hand, from the students' perspective, M-learning promotes their communication skills and collaborative learning with their peers. This happens because teachers have already prepared and organized all learning materials, including educational management cases or other issues, with highly interactive answers that are easily accessed on their students' phones.

The implementation of M-learning in university education has already attracted attention from practitioners and researchers, among others, [11], who conducted research to investigate the implementation of M-learning in educational learning. The trend of use technology in universities around the globe has tremendously grown fast[12]. They revealed that M-learning offers the flexibility to fulfil various current needs of students in learning, and it has the potential to optimize the available time to increase students' comprehension of educational management. Flexible assistance as offered by M-learning applications includes videos explaining concepts, steps of casesolving in educational management, and other tutorial materials. This type of assistance, in return, enables students to take more responsibility for their own learning, and it enhances their autonomy in Total Quality Management (TQM) learning. The utilization of M-learning in higher-education learning has resulted in the improvement of students' communication skills during class sessions, and more importantly, this type of application increases their comprehension related to materials [11]-[12]. The central factor in improvement is students' active discussions with their friends during class activities, where students are encouraged to exchange and share their thoughts with their friends about the materials they have already learnt. In other words, M-learning gives benefits to students because it provides a personalized learning experience. On the other hand, it facilitates students to improve not only their understanding, but also their communication skills. In this research, we adopted an Mlearning design in order to facilitate TQM learning. Specifically, the implementation of M-learning aims to facilitate two main activities:

- To enable students of Islamic Studies teachers to learn and practise Total Quality Management in mobile learning through delivery of materials, in written form or as interactive videos.

- To promote interactive discussions and communication skills from students of Islamic Studies during face-to-face learning.

The utilization of the M-learning teaching model in TQM learning is relatively new. However, reflection on class activities has a very important role in supporting the development and quality improvement of TQM learning. Reflective teaching gives a meaningful opportunity to collect information about what happens in class, and thereby identify successful activities. In order to understand the effectiveness of Mlearning, the researchers use two main instruments, a teaching journal and students' responses. The teaching journal is checked by our collaborator for the entire classes, while students' responses are collected using a survey that includes questions about learning materials, interactive videos, students' communication skills, and class 
activities, which are scored on a Likert scale. This reflective teaching has the potential to promote success in the future, to improve class practice.

\section{Theoretical Framework}

\subsection{Mobile learning in an Islamic classroom practice}

E-learning implementation, where mobile phone devices help in the learning process, can be defined as M-learning, according to Gyeung-Min Kim and Soo Min Ong [12], [13]. The current development of mobile phones makes the utilization of M-learning popular among the youth. This is because more diverse learning needs are being fulfilled, by mobile technology devices that can support the creation of more personalized learning process management [5], [17], [18]. Smartphone application developers have also developed countless implementations of educational applications, whether in terms of material explanation, assignments, or evaluations that can be modified and independently developed by teachers. The available applications enable teachers to implement more effective learning. In practice, teachers' creativity in delivering more interesting learning can become a challenge that deserves attention.

Currently, the concept of M-learning is also able to control the development of students' competence improvement through various learning evaluation instruments. Log history and history of activity in applications enable teachers to evaluate students' activities on a real-time basis. The developed report allows teachers to evaluate the ongoing learning practice. M-learning also offers a learning concept that can be independently evaluated by students. For instance, if students do not understand, they can relearn the materials. M-learning offers a learning concept which uses the availability of learning anytime, anywhere; this makes M-learning a learning model worth considering. Moreover, data have shown that the level of mobile phone use in students' daily activities is constantly increasing. M-learning still has the ability to develop as a navigation of education in the future [5], [7].

\subsection{Video interactive lecture}

Video utilization in M-learning practice has been widely used to improve students' learning experience; not only for independent learning, but also for reviewing learning materials. For example, if students do not understand some materials, they can watch a video to clarify unclear concepts. Videos for material explanation are designed to be of short duration, based on students' concentration level when they watch the video, so that they can learn more effectively. The method of delivering materials during Mlearning practice in this research is motivated by two main objectives: 
- To improve students' comprehension related to contents of material, whether inside or outside the school.

- To enhance basic TQM implementation skills, to solve educational problems in school.

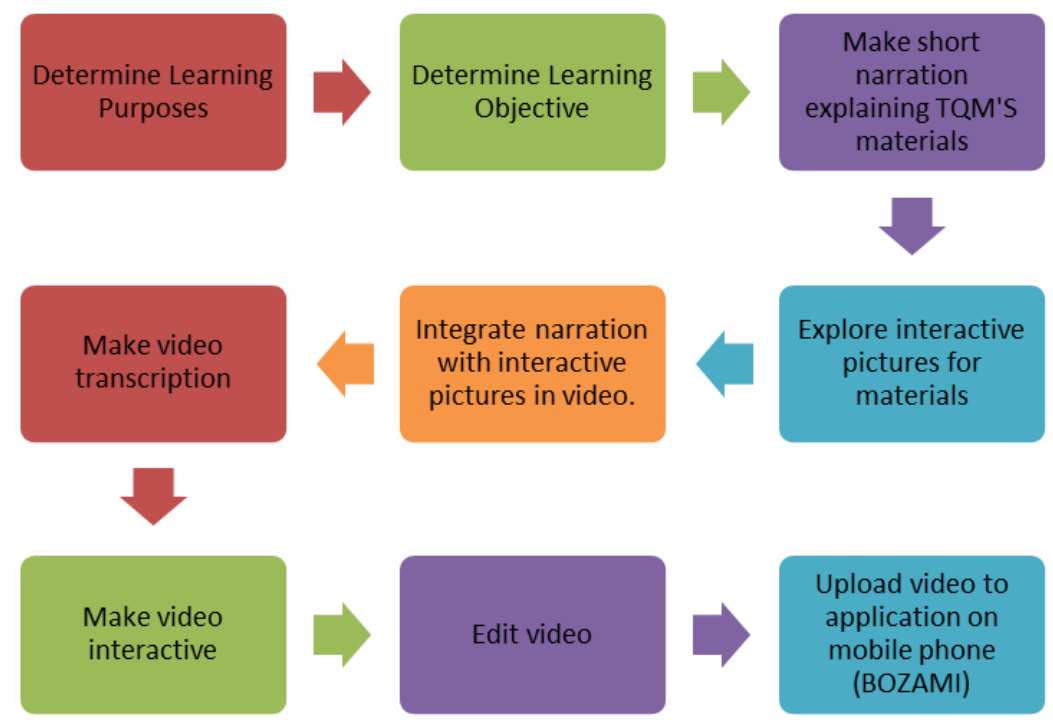

Fig. 1. Detailing steps of the development process of a video lecture.

A material explanation video is included as part of the M-learning which is being implemented. Creating it started by setting learning objectives and determining which material would be delivered. Each material consists of more than two short-duration videos, which required a preliminary draft of explanation. In order to add more attraction, the learning video was developed by adding interactive pictures adapted to the delivered materials. To minimize the risk of error, a video transcription was developed as voice maker, to explain the integrated materials with the interactive video. This video explains the main content of a subject, TQM, and is of 15 minutes' approximate duration; while several videos about school problems were intended to help students implement the basics of TQM in dealing with educational issues in the field (also lasting 15 minutes, on average).

\subsection{Instructional delivery method}

The Instructional Delivery Method (IDM) presented in this paper follows the procedure of [19], [20]. M-learning gives an opportunity to teachers to take advantage of students' habits that are intimately linked with mobile phone use and integrates two learning models: M-learning and face-to-face learning. The face-to-face element aims to: 
- Confirm students' comprehension during their study using M-learning.

- Facilitate learning that encourages the occurrence of interactive discussions.

- Hold class discussions for 120 minutes every week.

Learning practice in class discusses 12 topics for 12 face-to-face meetings, where the learning process is designed in a group form; it thereby supports the creation of discussion. Learning with a group design helps students become more active in discussion and allows them to understand each other's different comprehension levels, both individually and as a group. During class discussions, teachers facilitate group activity and support the creation of interactive discussions in the group. The practice of face-to-face learning in class follows a procedure that is planned as follows:

\section{Objective}

- To help pre-service teachers understand the basic concepts of Total Quality Management in education.

- To enable pre-service teachers to complete Total Quality Management of educational materials.

- To help pre-service teachers develop and design solutions by applying Total Quality Management related to school problems.

Textbook: Edward Sallis (2008), Total Quality Management in Education (Translated by Ahmad Ali Riyadi). Jogjakarta: IRCiSoD.

Time: Twelve sessions, 120 minutes per procedure:

- Step of Giving Problem Stimulus (15 minutes). Lecturer delivers a short speech related to the material, and provides issues related to Education Management that occur at levels of the school and the Municipal Education Authority.

- Step of Pre-Discussions (10 minutes). Students undertake discussions in small groups to find effective solutions for educational problems by implementing TQM material in education; including preparing the best solution from group discussions, in the form of essays and PowerPoint files.

- Step of Presentation (70 minutes). Students present the outcome of their discussion by implementing the TQM materials, with 10 minutes of maximum presentation time for each group.

- Step of Discussion (20 minutes). Students give responses respectively regarding the outcome of presentations by two other groups.

- Feedback from Teacher. (10 minutes). Teacher gives an appreciation of the explanation of the solution from whole groups, and gives feedback related to solutions presented in the class discussion session.

- Task (10 minutes). Teacher sets a task on mobile phones.

- Teacher's Feedback (15 minutes). Teacher gives feedback on given material, and requests responses from students regarding the learning process in each mobile phone application.

Learning practice in class focuses on the implementation of TQM materials in finding solutions to educational problems. Students' ability in solving problems is not 
only measured by their comprehension of materials, but also by teaching them unwritten technical solving techniques in school. To facilitate TQM learning outside class, we previously provided various materials, in the form of PowerPoint, essays, or interactive videos in a mobile application. The percentage of virtual activity in Mlearning is recommended to be from around $20 \%$ up to $80 \%$ [21]. In the context of this research, the objectives are to utilize mobile phones to replace face-to-face or conventional meetings for explaining learning materials, and also for measuring comprehension with a session of multiple-choice tasks in a short time. Specifically, M-learning has the following objectives:

- To provide independent learning for students through a mobile application prepared by the teacher.

- To help students to improve their comprehension of TQM in education.

- To give material explanation, whether in the form of PowerPoint, essays, and interactive videos that are integrated with reference books.

In implementing M-learning, interactive videos with short duration were already prepared to help students to understand materials from the reference book. Roux and Nagel [21] state that a short-duration video gives alternative solutions in explaining materials, especially to students who are lazy about reading books. The format of interactive videos with short duration aims to enable students to concentrate on understanding TQM's materials. According to Beatty et. al. [22], short-duration video learning is more effective than long-duration because students' concentration on video-learning is very limited. M-learning with various types of learning assistance has already supported students' awareness to learn independently, whether at home or in school.

\section{$3 \quad$ Research Method}

\subsection{Reflective teaching}

Reflective teaching is considered to be an alternative that helps promote teachers' professional development. This situation gives teachers an extraordinary opportunity to look at the principles and fundamental beliefs which have a major impact on their practice in class. Reflective activity can be an effective tool not only for creating teachers' profiles, but also to enhance students' learning environment. The main goal of reflective learning is to conduct in-depth investigation of teachers' practice, in order to comprehensively understand how to improve students' learning. Investigating teaching practice in class gives information about activities that need to be improved, along with aspects to be retained, in order to help achieve more effective class practice in the future.

In conducting reflective teaching, we used several instruments, such as selfobservation, students' journals and questionnaires. These instruments have been seen in previous reflective practice study. Self-observation can help to check teaching practice through simple actions, such as teachers taking notes when they realize their 
mistakes. Reflection needed to be supported by the results from students' questionnaires, as a response to past experience; this involved conscious withdrawal and experience checks, as a foundation for evaluation and making decisions, and also as a source of planning and action. Responses from students were the biggest source of teaching evaluation to help improve the quality of teaching practice. It was anticipated that these various reflective teaching instruments would support and motivate us to provide more effective teaching in class practice in the future.

\subsection{Participants' demographics}

A total of 64 pre-service teachers who enrolled in a model maths course, consisting of 12 men and 52 women, were involved in our M-learning practice. Our observation before this research showed that they can operate the Google Play application, including the ability to search for Wi-Fi networks on mobile phones, open a learning application called BOZAMI, and deliver presentations using PowerPoint. Students can also operate internet search engines, correspond via email, upload and download applications and files from mobile phone applications. In addition to these mobile phone application skills, they can connect smartphones to computers and laptops, especially when transferring data from smartphone applications to computers or laptops.

Table 1. Demographic features of the sample studied.

\begin{tabular}{|l|c|l|c|}
\hline \multicolumn{1}{|c|}{ Characteristics } & Percentage & \multicolumn{1}{c|}{ Characteristics } & Percentage \\
\hline Duration of mobile device use for learning & & \multicolumn{1}{|c|}{ Age } & $46 \%$ \\
\hline Less than 6 months & $28 \%$ & Male & $54 \%$ \\
\hline Between 6 and 12 months & $54 \%$ & Female & \\
\hline More than 12 months & $18 \%$ & & $14 \%$ \\
\hline \multicolumn{1}{|c|}{ Learning Achievement Level } & & & $74 \%$ \\
\hline Below & $34 \%$ & Below 21 & $12 \%$ \\
\hline Middle & $44 \%$ & Between 20 and 21 & \\
\hline High & $12 \%$ & 21 and above & \\
\hline
\end{tabular}

\subsection{Data collection method and analysis}

In implementing reflection on M-learning in the TQM class, data collection methods included self-observation, students' journals, and a students' questionnaire. Self-observation enables teachers to evaluate and develop learning practice quality, to improve learning conditions in class [20]. In implementing self-observation, teachers collected information from class discussion and students' feedback, produced in two forms during outside-class learning, through the M-learning workshop and students' journals. Students were also asked to complete a survey related to the implementation of M-learning in the classroom, and an M-learning workshop before learning in class. Umam, et. al [19] suggest that the collected data from self-observation and students' journals is analysed using content analysis, which adopts the following procedure [23], [24]. First, observation and students' journals were given coloured codes based 
on the emerging themes, which were further managed to determine patterns and calculate their frequency. Eventually, the frequency and code patterns were applied to the sessions of reflection, discussion and outline. The outcomes of the questionnaire from students were statistically analysed, presented as the mean calculation (M) and standard deviation (SD).

\section{$4 \quad$ Findings and Discussion}

This part will present the findings obtained from critical reflection on M-learning teaching of Total Quality Management material, in educating Islamic Studies teachers. The following themes emerged from reflection.

\subsection{Superiority of m-learning}

M-Learning encourages students to learn more independently: it also offers time flexibility, which enables students to learn outside class. Students are no longer limited by time, as shown by several students saying that even in a traffic jam, they can still use their time in public/private transportation for learning activities, with both new and previous materials. They learnt most materials before the class started. This situation shows that they have high awareness of learning independently; this awareness is a crucial part of the learning process, because it promotes various other independencies in learning. This is demonstrated by the many students who searched and confirmed their comprehension by comparing the delivered materials on $\mathrm{M}$ learning with materials available on YouTube or other websites. This awareness emerged based on their strong sense of curiosity and willingness to understand the materials more deeply.

After class dismissal, students who have not understood the material can revisit it on their mobile phone. Students can easily access previous materials that enable them to learn more independently. Introducing learning by mobile phone is new in our class practice, and most students did not understand how to operate their phone to learn independently. Before meetings started, we had already prepared an M-learning workshop for students participating in this research, so that they would not be surprised when learning practice took place. They were taught how to open learning materials on their mobile phone. Most students were learning with the BOZAMI application for the first time; this enables them to learn materials from their mobile phones. Thus, the phones they own today can not only be used use to communicate, but also for independent learning. M-learning alerts students to learning opportunities, and increases their curiosity, which encourages them to learn more.

M-learning has created a highly interactive discussion atmosphere among students in class learning. Students' habit of learning before entering the class has increased their comprehension of materials, because they can learn from existing materials on their phone before learning in the classroom. Good comprehension of materials increases students' confidence in giving opinions during discussion, when it is seen that students have the ability to convey clear statements based on the delivered 
presentation. Students' statements which are relevant and qualified demonstrate the success of delivering materials via M-learning. This situation proves that students' powerful comprehension will improve their ability to construct arguments about things being discussed. Discussion also teaches students to try to understand somebody else's main ideas, and assess the perspective of other individuals. Active communication among discussion participants encourages various opinions, and thereby creates a very interactive discussion atmosphere. Furthermore, discussion teaches students to listen to other students' opinions, so that arguments emerge to further explore the materials. Interactive discussions that support the creation of a learning atmosphere can result in collective comprehension, so that learning goals are achieved.

M-learning improves students' communication ability. The habits created by Mlearning encourage students to communicate, whether discussion takes place inside or outside the classroom. Discussion that takes place in the classroom is very important [5], [19] because it affects the entire team's awareness, so that one student with others are need to each other. They can confirm their comprehension with friends in the same team, who possibly have different perspectives. Each student gives an opinion based on materials they have learnt, and provides comments based on other statements [13]. Trying to understand and listen to others' opinions are communication skills that ought to be acquired by students.

Students' ability in communication gradually improves, whether communication happens via mobile applications or during classroom learning [25]. Class learning that is designed based on groups enables students to develop their communication during discussion. Moreover, class learning which relates to problems that happen in school encourages students to implement Total Quality Management materials. Each group had an obligation to convey their perspective on problem-solving. An interesting outcome in class was that each group had various perspectives on problem-solving. Their presentation was not delivered by one only person, but by all members of the group, because each of them had an opportunity to speak in front of the class during presentation time. This also indicates a collective awareness that idea of the solution ought to be provided by the whole team. Thus, communication that happens outside the class improves students' confidence to give opinions in front of the class. This ability to deliver ideas in front of the class greatly supports students' selfimprovement in the future [26]. It becomes valuable capital, because students are able to express their ideas in front of people. To support reliability in the assessment of students' communication improvement, the researcher provided a questionnaire, adopted from [27], after delivering the materials, as follows: 
Table 2. Report on student' responses regarding communication skill improvement in classroom practice

\begin{tabular}{|c|c|c|c|}
\hline & Statements & Mean & SD \\
\hline 1 & $\begin{array}{l}\text { In class discussion, I summarize and check what was said by others, and then go back } \\
\text { to the debate to convey opinions. apa yang saya yakini }\end{array}$ & 4.46 & 0.50 \\
\hline 2 & $\begin{array}{l}\text { I try to make my own conclusions after learning by mobile phone, and check whether I } \\
\text { understood correctly during discussion. } \\
\text { I put myself in the other person's (side's) shoes while leading the conversation. }\end{array}$ & 4.29 & 0.60 \\
\hline 3 & I put myself in someone else's position while leading class or group discussion. & 4.56 & 0.59 \\
\hline 4 & $\begin{array}{l}\text { In class discussion, I'm more focused on understanding others' arguments than } \\
\text { criticizing. }\end{array}$ & 4.20 & 0.68 \\
\hline 5 & $\begin{array}{l}\text { I keep open to others' opinions although they are different from my own, and I try to } \\
\text { understand. }\end{array}$ & 4.61 & 0.59 \\
\hline 6 & $\begin{array}{l}\text { I pay attention to words said by others, because people may have different perspectives } \\
\text { on materials provided by mobile phone. }\end{array}$ & 4.46 & 0.55 \\
\hline 7 & $\begin{array}{l}\text { I lead the communication or discussion, even though I meet people from different } \\
\text { groups. }\end{array}$ & 4.34 & 0.73 \\
\hline 8 & $\begin{array}{l}\text { I am confident in using facial expressions and body language as well as verbal } \\
\text { expression, to express the argument that I want to convey. }\end{array}$ & 4.22 & 0.72 \\
\hline 9 & $\begin{array}{l}\text { I'm already thinking and organizing what I'm going to say before I say it, and try to do } \\
\text { it every time they show up. }\end{array}$ & 4.32 & 0.72 \\
\hline 10 & I understand others by reading their facial expression or movements. & 4.32 & 0.72 \\
\hline 11 & I try to think about my friends' feelings if I yell during discussion. & 4.27 & 0.74 \\
\hline 12 & $\begin{array}{l}\text { During conversation, I keep thinking about how others will understand and interpret my } \\
\text { comments. }\end{array}$ & 4.68 & 0.47 \\
\hline
\end{tabular}

SD: Standard Deviation, M: Mean.

The interesting outcome from these students' responses is that they try understand others' opinions during discussion. For instance, "I pay attention to words said by others, because people have different perspectives" receives $\mathrm{M}(4.46) \mathrm{SD}(0.55)$; "I put myself in someone else's position while leading class or group discussions" receives $\mathrm{M}(4.56) \mathrm{SD}(0.59)$; and "I keep open to others' opinions although they are different from my own, and I try to understand" receives $\mathrm{M}(4.61) \mathrm{SD}(0.59)$. This shows the improvement in students' awareness of respecting each other during communication with others. Students have also learnt to respect others and confirm each other's opinion, which creates inter-communicative learning in the teaching-learning process.

Learning with mobile phones helps most students to learn independently [28]. However, the research found that some of them were unable to properly manage their time. We found that students did not learn the materials at home. Mobile phones always distracted their attention away from learning to playing games, especially for male students. For example, male students tended to use their phones to play games than using it for learning. Even if they had already allocated the time, they realized that playing games always comes first. Not all males used their phones to play games; some tended to look at learning on their phones. Students who lack learning motivation will encounter difficulties in learning independently. To accommodate independent learning, we asked students to go online at an agreed time, whether to do the tasks or simply to learn the materials. Agreement in deciding a time teaches 
students about discipline in independent learning [7]; this supports the creation of students' habit of learning independently[29],[30].

Although learning with technology offers an alternative solution for doing tasks or tests, M-learning is still unable to support grading in essay tests. One of the most challenging aspects was assessment by mobile phone when the teacher asked students to write an essay. Smartphones were able to document the results of our grading in digital documents [5], [31]; however, technical matters in dealing with essays need to be considered during M-learning's implementation. We offered a solution by giving students an opportunity to use their laptop during an essay test and uploading their outcome to their mobile phone. This alternative solution offers not only technical simplicity in conducting essay tests for students, but also helps teachers to document students' test outcomes digitally on the M-learning application.

\subsection{Technical issues}

Workshop for mobile learning: A workshop for learning preparation before Mlearning's implementation is highly recommended. It aims to reduce the comprehension disparity between teacher and students, regarding the application's utilization in classroom learning practice. Technical aspects need to be covered by gathering all students first, to introduce which application will be used during learning. Workshop materials were divided into four parts: the utilization of mobile phones for learning, examinations, doing the tasks, and assessing students' comprehension development. This M-learning workshop was conducted on two days, for eight hours, in a room already provided with an appropriate internet service. The outcome of the evaluation uses an instrument adopted from [32] about students' responses regarding the implementation of the mobile phone learning workshop can be seen in Table 2, as follows:

Table 3. Evaluation of the training method, training materials and trainers.

\begin{tabular}{|c|c|c|c|}
\hline & Statements & Mean & SD \\
\hline & \multicolumn{3}{|l|}{ Training } \\
\hline 1 & $\begin{array}{l}\text { The objectives of the M-learning workshop sessions were very clearly defined and } \\
\text { represented. }\end{array}$ & 4.68 & 0.47 \\
\hline 2 & Technical simulations both in and outside the class were clearly represented/conducted. & 4.39 & 0.63 \\
\hline 3 & The ratio between theoretical training and M-learning practice was satisfactory. & 4.24 & 0.62 \\
\hline \multirow[t]{2}{*}{4} & The amount of time allotted to practice was satisfactory. & 4.02 & 0.69 \\
\hline & \multicolumn{3}{|l|}{\begin{tabular}{|c|} 
Training Materials \\
4.03 \\
0.823 \\
\end{tabular}} \\
\hline 1 & The applications (video, audio, slide presentation) were satisfactory. & 4.46 & 0.55 \\
\hline 2 & The equipment and disposables were satisfactory. & 4.29 & 0.72 \\
\hline 3 & The manual books were in good condition. & 4.24 & 0.62 \\
\hline 4 & The checklists produced and the observation grids prompted me to think critically. & 4.44 & 0.71 \\
\hline 5 & $\begin{array}{l}\text { The checklists produced and the observations grids prompted me to search for scientific } \\
\text { evidence. }\end{array}$ & 4.56 & 0.59 \\
\hline 6 & I may use the checklists produced and the observation grids as reference in the future. & 4.24 & 0.62 \\
\hline
\end{tabular}




\begin{tabular}{|c|l|c|c|}
\hline & \multicolumn{1}{|c|}{ Trainers } & \multicolumn{1}{|c|}{} \\
\hline 1 & Were communicative & 4.54 & 0.50 \\
\hline 2 & Provided satisfactory answers to student questions & 4.44 & 0.59 \\
\hline 3 & Were approachable & 4.32 & 0.52 \\
\hline 4 & Cooperated with the students & 4.29 & 0.72 \\
\hline 5 & $\begin{array}{l}\text { I would like to participate in a similar M-learning workshop again, and to be contacted } \\
\text { over a long-term period. }\end{array}$ & 4.46 & 0.64 \\
\hline
\end{tabular}

SD: Standard Deviation, M: Mean.

Looking at the students' response outcomes, it is shown that students have the intention to follow this workshop activity further in a longer period of activity. Workshop activity is very useful to candidates, not only in learning about Mlearning's implementation [33], but it also inspires them to do the same thing during their later teaching practice. One of the opinions stated that "M-Learning is very useful for study and for my teaching practice, later. I will also use this application in my teaching practice in school". Using a workshop for M-learning not only offers benefits during M-learning's implementation, but also gives experience that enables students of Islamic Studies teachers to implement it during teaching practice in school.

M-learning is an application which needs internet access, and frequently this prevents students from learning. Limited internet access can be one of the biggest problems in implementation. Fulfilling this internet requirement is essential for successful implementation of M-learning practice activity in class [34]. Several students lacked stable internet access, and thereby missed certain points during assignment time. An alternative solution is to provide proper minimum internet access in the school's facility, so that during implementation, M-learning in class can be conducted more effectively.

\section{Conclusion}

This research had the main objective of understanding the effectiveness of Mlearning through reflective teaching. The reflection on M-learning's implementation showed that the main problems were technical, so that skills development and habitual action are needed to make M-learning implementation successful. M-learning is a very unfamiliar experience for students, because they have to initially learn their lessons at home. Nevertheless, it encourages collaborative learning and creates an environment for peer teaching. Independent learning before class learning is challenging and needs efforts from students. Diligent students have high motivation, and students who encounter problems need help from their peers in terms of comprehension, in order to encourage the establishment of peer teaching among students. 


\section{References}

[1] J. A. L. Yeap, T. Ramayah, and P. Soto-acosta, "Factors propelling the adoption of mlearning among students in higher education," Electron. Mark., pp. 323-338, 2016, https:// doi.org/10.1007/s12525-015-0214-x.

[2] N. H. Zakaria, F. A. Phang, and J. Pusppanathan, "Physics on the Go: A Mobile ComputerBased Physics Laboratory for Learning Forces and Motion," vol. 14, no. 24, pp. 167-183, 2019. https://doi.org/10.3991/ijet.v14i24.12063

[3] A. Mueangpud, J. Khlaisang, and P. Koraneekij, "Mobile Learning Application Design to Promote Youth Financial Management Competency in Thailand," Int. J. Interact. Mob. Technol., vol. 13, no. 12, pp. 19-38, 2019. https://doi.org/10.3991/ijim.v13i12.11367

[4] A. U. A. E. Case, J. Eppard, Z. Hojeij, and P. Ozdemir-ayber, "Using Mobile Learning Tools in Higher Education," vol. 13, no. 11, pp. 51-69, 2019. https://doi.org/10.3991/i jim.v13i11.10823

[5] F. J. Tapia-Moreno and H. A. Villa-martinez, "Digital Learning Tools for Mobile Devices for Accomplish Hypothesis Testing of Statistical Parameters," Int. J. Interact. Mob. Technol., vol. 13, no. 6, pp. 15-26, 2019. https://doi.org/10.3991/ijim.v13i06.10436

[6] M. M. The and T. Usagawa, "Investigation of Students' Mobile Phone Usage and Influences towards Their Mobile Learning Adoption: A Case Study in Myanmar,” Int. J. Interact. Mob. Technol., vol. 12, no. 5, pp. 43-57, 2018. https://doi.org/10.3991/ijim.v12i5. $\underline{8924}$

[7] M. Alshurideh, "Understanding the Quality Determinants that Influence the Intention to Use the Mobile Learning Platforms: A Practical Study,” Int. J. Interact. Mob. Technol., vol. 13, no. 11, pp. 157-183, 2019. https://doi.org/10.3991/ijim.v13i11.10300

[8] N. Cavus and D. Ibrahim, "MOLT: A Mobile Learning Tool That Makes Learning New Technical English Language Words Enjoyable," Int. J. Interact. Mob. Technol., vol. 2, no. 4, pp. 38-42, 2008.

[9] Suswandari, L. Armiyati, K. Umam, N. Asiah, and E. N. Susanti, "Improving Jakarta historical understanding ability through inquiry learning model assisted with ICT among junior high school students," 2017.

[10] V. Septiany, S. E. Purwanto, and K. Umam, "Influence of learning on realistic mathematics ICT-Assisted mathematical problem-solving skills students," 2015.

[11] M. Sarrab, "M-learning in education: Omani Undergraduate students' perspective," Procedia - Soc. Behav. Sci., vol. 176, pp. 834-839, 2015, https://doi.org/10.1016/j.sbspro. 2015.01.547.

[12] S. Papadakis, M. Kalogiannakis, E. Sifaki, and N. Vidakis, "Evaluating Moodle use via Smart Mobile Phones. A case study in a Greek University," EAI Endorsed Trans. Creat. Technol., vol. 5, no. 16, pp. 1-9, 2018, https://doi.org/10.4108/eai.10-4-2018.156382.

[13] W. Kusmaryani, B. Musthafa, and P. Purnawarman, "The influence of mobile applications on students' speaking skill and critical thinking in English language learning The influence of mobile applications on students' speaking skill and critical thinking in English language learning," in International Conference of Computer and Informatics Engineering (IC2IE), 2019, pp. 1-6, https://doi.org/10.1088/1742-6596/1193/1/012008.

[14] V. Septiany, S. E. Purwanto, and K. Umam, "Influence of learning on realistic mathematics ict-assisted mathematical problem-solving skills students," 2015.

[15] G. Kim and S. M. Ong, "An Exploratory Study of Factors Influencing M- Learning Success,” J. Comput. Inf. Syst., vol. 46, no. 1, pp. 92-97, 2005.

[16] S. Papadakis, M. Kalogiannakis, E. Sifaki, and N. Vidakis, "Access moodle using smart mobile phones. A case study in a Greek University," in Interactivity, Game Creation, 
Design, Learning, and Innovation, Crete, Greece: Springer, 2017, pp. 376-385. https://doi. org/10.1007/978-3-319-76908-0 36

[17] M. W. Easterday, D. R. Lewis, and E. M. Gerber, "Design-Based Research Process: Problems, Phases , and Applications Problems arising from the ill-definition of DBR," Learn. Become Pract. (ICLS 2014), p. 322, 2014, [Online]. Available: http://www.isls.org/icls2014

[18] Q. Zhang and F. Wu, "State-of-the-Art and Future Directions of Smart Learning," in Stateof-the-Art and Future Directions of Smart Learning, Y. Li et a., Singapore: Lecture Notes in Educational Technology, 2016, pp. 257-261. https://doi.org/10.1007/978-981-287-8687_9

[19] K. Umam, T. Nusantara, I. N. Parta, E. Hidayanto, and H. Mulyono, “An Application of Flipped Classroom in Mathematics Teacher Education Programme,” Int. J. Interact. Mob. Technol., vol. 13, no. 03, p. 68, 2019, doi: 10.3991/ijim.v13i03.10207. https://doi.org/10. 3991/ijim.v13i03.10207

[20] N. (Universitas M. P. D. H. Solihati and H. (Universitas M. P. D. H. Mulyono, “A Hybrid Classroom Instruction in Second Language Teacher Education (SLTE): A Critical Reflection of Teacher Educators," Int. J. Emerg. Technol. Learn., vol. 12, no. 5, pp. 169180, 2017. https://doi.org/10.3991/ijet.v12i05.6989

[21] I. le Roux and L. Nagel, "Seeking the best blend for deep learning in a flipped classroom viewing student perceptions through the Community of Inquiry lens," Int. J. Educ. Technol. High. Educ., vol. 15, no. 1, 2018, https://doi.org/10.1186/s41239-018-0098-x.

[22] B. J. Beatty, Z. Merchant, and M. Albert, "Analysis of Student Use of Video in a Flipped Classroom," TechTrends, no. Karnad 2013, pp. 1-10, 2017, doi: 10.1007/s11528-0170169-1.

[23] C. R. Rayford, "Reflective practice: The teacher in the mirror," Graduate College University of Nevada, Las Vegas, 2010.

[24] E. S. Alim, K. Umam, and S. Rohim, "Integration of reciprocal teaching-ICT model to improve students' mathematics critical thinking ability," 2015.

[25] S. Naidu and M. Oliver, "Critical incident-based computer supported collaborative learning,” Instr. Sci., vol. 27, no. 2, pp. 329-354, 1999. https://doi.org/10.1007/bf008920 $\underline{30}$

[26] K. Umam, Suswandari, N. Asiah, I. T. Wibowo, and S. Rohim, "The effect of think-pairshare cooperative learning model assisted with ICT on mathematical problem-solving ability among junior high school students," 2017.

[27] Y. Chung, J. Yoo, S. Kim, H. Lee, and D. L. Zeidler, "Enhancing Students" Communication skills in the science classroom through socioscientific issues," Int. J. Sci. Math. Educ., vol. 14, no. 1, pp. 1-27, 2014. https://doi.org/10.1007/s10763-014-9557-6

[28] H. C. Wong, "A study of mobile learning for higher education students in Guangzhou," vol. 3, no. Suppl 1, pp. 1-2, 2014, https://doi.org/10.1186/2193-1801-3-s1-p3.

[29] S. Iqbal and Z. A. Bhatti, "What drives m-learning? An empirical investigation of university student perceptions in Pakistan," High. Educ. Res. Dev., vol. 0, no. 0, pp. 1-17, 2016, http://doi.org/10.1080/07294360.2016.1236782 .

[30] H. C. Wong, "A study of mobile learning for higher education students in Guangzhou," Springerplus, vol. 3, no. Suppl 1, p. P3, 2014, https://doi.org/10.1186/2193-1801-3-s1-p3.

[31] S. M. Ismail and G. Barreto, "How to Improve the Accessibility and Reduce the Total Cost of Ownership with ECOLIG Protocol and Android in Mobile Learning," Int. J. Interact. Mob. Technol., vol. 5, no. 4, pp. 11-16, 2011. https://doi.org/10.3991/ijim.v5i4.1648 
[32] A. Bagnasco, N. Pagnucci, A. Tolotti, F. Rosa, G. Torre, and L. Sasso, "The role of simulation in developing communication and gestural skills in medical students," pp. 1-7, 2014. https://doi.org/10.1186/1472-6920-14-106

[33] L. Grant, "Mobimissions': A Locative, Mobile, and Collaborative Experience using Cellular networks," in Beyond Mobile Learning Workshop, I. Arnedillo-Sánchez, G. Vavoula, and M. Sharples, Eds. 2007, pp. 22-23.

[34] A. Ahmed, A. Zahid, H. Wajid, H. R. Muhammad, and S. Vighio, "An analysis of the influence of a mobile learning application on the learning outcomes of higher education students," Univers. Access Inf. Soc., vol. 17, no. 2, pp. 325-334, 2018, https://doi.org/10. $\underline{1007 / \mathrm{s} 10209-017-0551-\mathrm{y}}$

\section{$7 \quad$ Authors}

Bunyamin is a lecturer at Faculty of Teacher Training and Pedagogy, Universitas Muhammadiyah, Prof. Dr. Hamka (UHAMKA). His research interests include mathematics teaching, ICT in the classroom

Khoerul Umam is a lecturer at Faculty of Teacher Training and Pedagogy, Universitas Muhammadiyah, Prof. Dr. Hamka (UHAMKA). His research interests include management in education, technology in education.

Lismawati is a lecturer at Faculty of Teacher Training and Pedagogy, Universitas Muhammadiyah, Prof. Dr. Hamka (UHAMKA). His research interests include Islamic studies, technology in education.

Article submitted 2020-04-22. Resubmitted 2020-09-20. Final acceptance 2020-09-20. Final version published as submitted by the authors. 